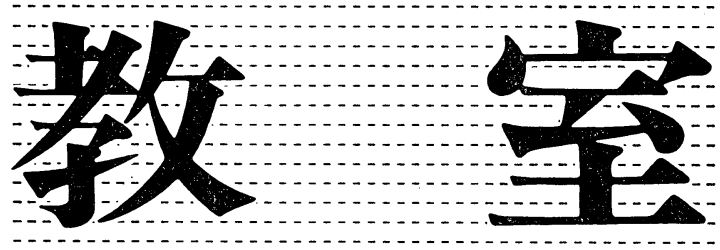

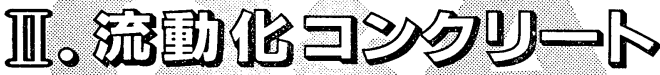

(घㅁำ)

\begin{tabular}{|l|l|}
\hline Q13 & $\begin{array}{l}\text { 流動化コンクリートの圧縮強度は } \\
\text { ベースコンクリートとほぼ同等と考 } \\
\text { えてょいのでしょうか。 }\end{array}$ \\
\hline
\end{tabular}

流動化剂は，一般には液状で使用されます

[A] ので, コンクリートの水セメント比はベース コンクリートより若干大きくなり，その分だ け強度低下があるのではと考えられますが, 通常の使用 量によって変化する水セメント比は $0.3 \%$ 程度であり, また流動化㓮のセメント分散性による効率の向上もあり ますので, 強度に及ぼす影響は無視できる程度とされて います。

流動化の前後におけるコンクリートの圧縮強度につい ては, セメントの種類 ${ }^{1)}$, ベースコンクリートのスラン プの值, 流動化の時期 ${ }^{2)}$, 流動化の程度 ${ }^{2)}$, 材令 ${ }^{3}$ 等の影 響について多くの実験結果が報告されていますが, いず れの場合も, 流動化コンクリートの圧縮強度はベースコ ンクリートの圧縮強度に対して, 空気量がほぼ同等であ

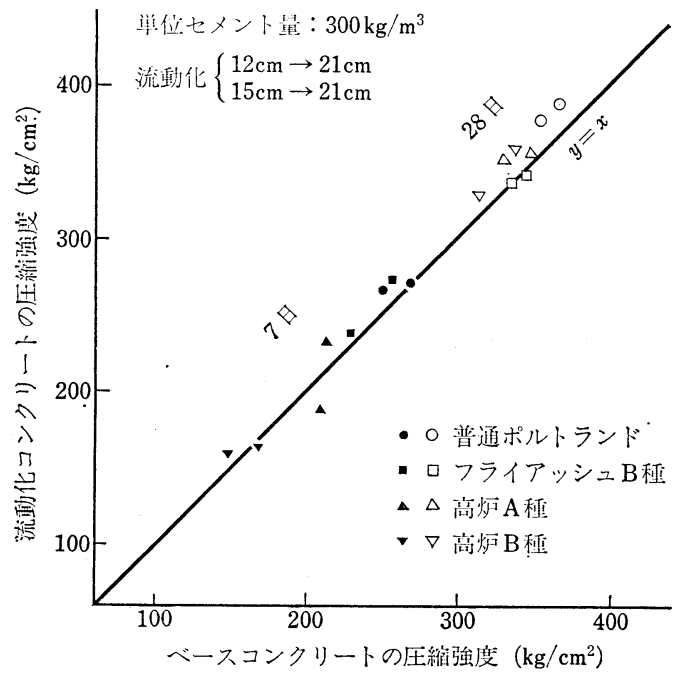

図-13.1 流動化剂添加前後の圧縮強度 ${ }^{1)}$.

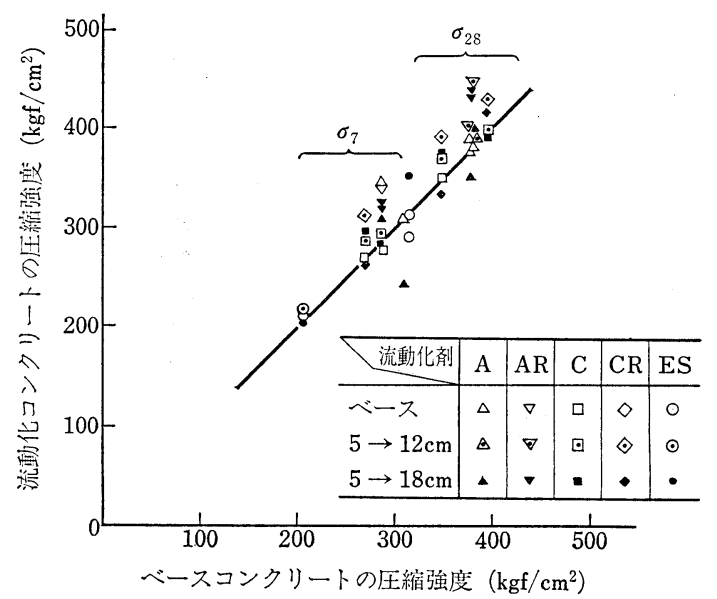

図一13.2 ベースコンクリートと流動化コンクリート の圧縮強度 ${ }^{2}$

れば有意な差は認められず，同等と扱ってよいといら結 果が示されています。

流動化コンクリートとベースコンクリートの圧縮強度 に差が認められる原因のほとんどは空気量の差にあるよ らで, 圧送後の強度は全般に大きくなることが認められ ています。

\begin{tabular}{|l|l|}
$\mathbf{Q} 14$ & $\begin{array}{l}\text { 流動化コンクリートの圧縮強度以 } \\
\text { 外のカ学的性質について教えて下さ } \\
\text { い。 }\end{array}$ \\
\hline
\end{tabular}

コンクリートの一般的物性は，ほぼ圧縮強

[A] 度に比例することが知られていますが，流動 化コンクリートにおいても同様に考えて差支 えないようです。

(1) 曲げ強度

流動化後の曲げ強度は, ベースコンクリートと同等か または若干低下する傾向にあるようですが，その差は小 さく, 同一スランプの通常のコンクリートよりは大きく 


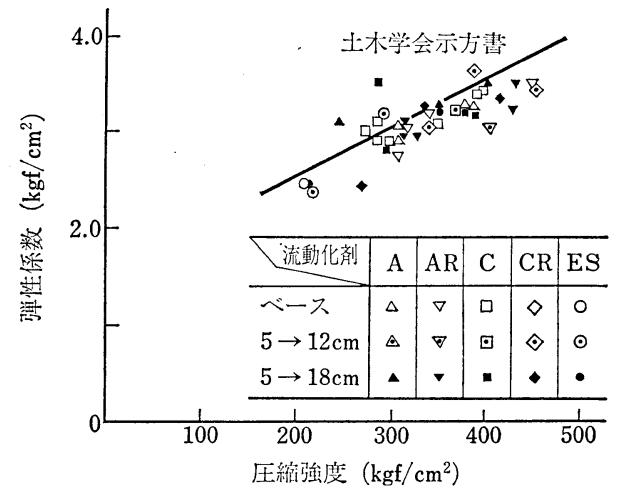

図一14.1 圧縮強度と静弾性係数 ${ }^{2)}$

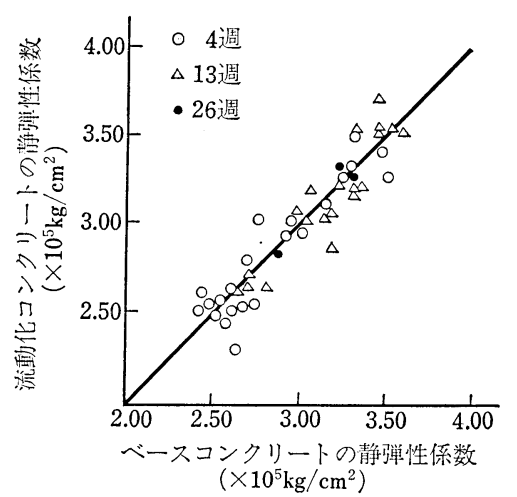

図一14.2 流動化剂添加前後の静弾性係数の比較 ${ }^{8}$

なります2) 4)。

(2) 引張強度

試験例は少ないようですが, 圧縮強度と同様に流動化 による影響は認められず, 引張強度/圧縮強度は, ベー スコンクリート抢よび流動化コンクリートとも 1/9 1/12 の範囲にあり, 通常のものと 同等といえるようで 于 $^{1)}$ 。

\section{（3） 静弾性係数}

ベースコンクリートおよび流動化コンクリートの静弾 性係数の関係は, 図一14.1, 14.2 に示されるように同 等で, 圧縮強度と静弹性係数の関係は, 建築学会および 土木学会の式によって表すことができることも認められ ており ${ }^{1) \sim 3)}$, 流動化コンクリートの静弾性係数は, 一般 のコンクリートと同様に扱っても問題はありません。

\section{（4）鉄筋の付着強度}

鉄筋の付着強度は, 一般にブリージング量の小さい方 が大となることが知られています。流動化コンクリート は, 同一スランプの通常コンクリートよりブリージング が少なく, 従って付着強度は大きくなりますが, ベース コンクリートに対しては同等か若干小さくなる傾向が認 められています2)。

(5) 乾燥収縮

Vol. 24, No. 8, Aug. 1986
流動化コンクリートの乾燥収縮は, ベースコンクリー トとほぼ同等で, 同一スランプの通常コンクリートに対 しては 10 15\% 程度小さくなることが認められてお り，ひびわれ低滅にかなりの効果が期待されています。

(6) クリープ

流動化コンクリートのクリープは, 載荷当初はベース

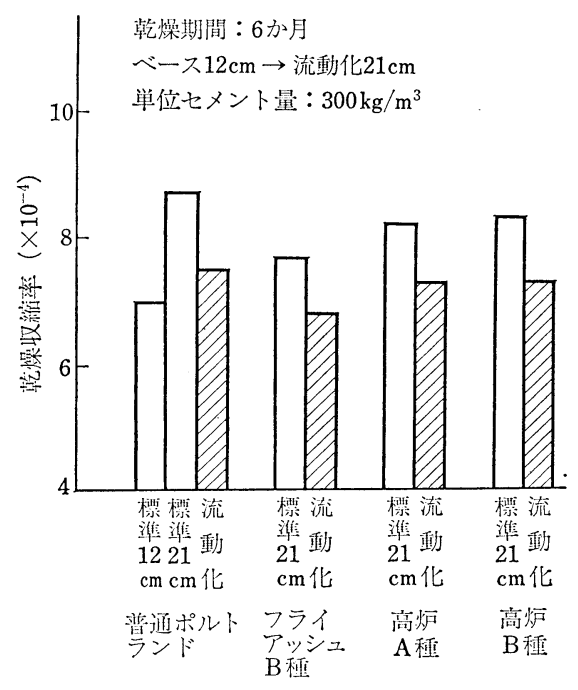

図一14.3 コンクリートの乾燥収縮 ${ }^{1}$

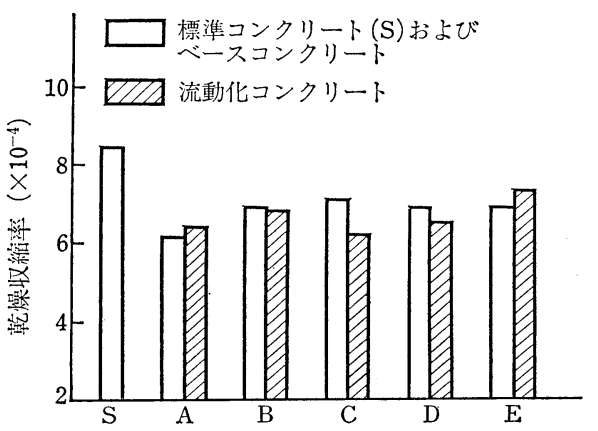

$\mathrm{S}:$ 標準コンクリート $(\mathrm{AE}$, スランプ $21 \mathrm{~cm})$ $A \sim D ：$ 市販流動化刘

(ベースコンクリートは $\mathrm{AE}$ ，スランプ $12 \mathrm{~cm}$ )

$\mathrm{E}:$ 遅延形特殊減水剂

乾燥期間 6 週

図一14.4 流動化コンクリートの乾燥収縮 ${ }^{3}$

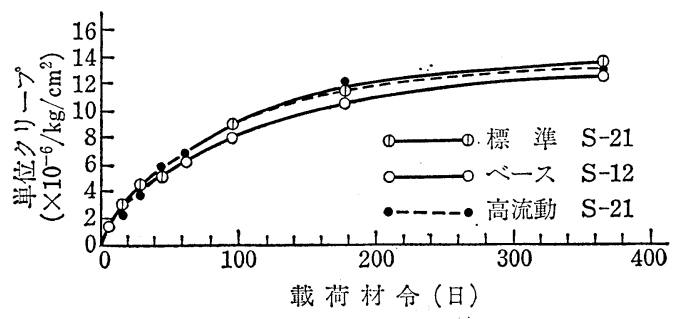

図-14.5 圧縮クリープ試験結果 $3:$ 
コンクリートと同程度ですが，長期では，ベースコンク リートよりやや大きくなりますが，同一スランプの通常 コンクリートと同程度とされています吕, 。

\section{（7） 耐凍結融解性}

一般に, 凍結融解に対する抵抗性を増大させるために は適量の空気泡の存在が有効ですが, 流動化コンクリー トも同様で, 適正な空気泡があれば耐凍結融解性は良好 となります。

（8）その他

透水性, 耐磨耗性, 耐化学薬品性, 耐熱性等は, いず れもベースコンクリートとほぼ同等で, 同一スランプの 通常のコンクリートよりは優れているといえます。

\begin{tabular}{|c|l|}
\hline Q15 & $\begin{array}{l}\text { 流動化コンクリートを使用すると } \\
\text { 乾燥収縮率は小さくなるとされてい } \\
\text { ますが, 実際のひびわれはどの程度 } \\
\text { 減少するのか教えて下さい。 }\end{array}$ \\
\hline
\end{tabular}

流動化コンクリートが採用される目的は,

[A] 建築関係では品質の向上, 土木関係では施工 性の改良が主なものとなっていますが，特に 建築での採用理由の大部分は, ひびわれの低減が目的と されているようです。

流動化コンクリートの乾燥収縮は, 前述のようにベー スコンクリートとほぼ同等で, 通常の軟練りコンクリー トよりは 10 15\% 程度小さくなることが認められてい ますので, 流動化コンクリートを使用した建築物の乾燥 収縮によるひびわれの発生量は, 通常の軟練りコンクリ ートを使用した場合よりは少なくなることは十分考えら れます。建築物のひびわれは乾燥収縮によるものだけと は限られず，他にも種々の要因がありますので，一概に 流動化コンクリートを使用したことにより，ひびわれの 発生量が何パーセント小さくなるとはいえませんが，流 動化コンクリートを使用した工事記録等では，ほとんど

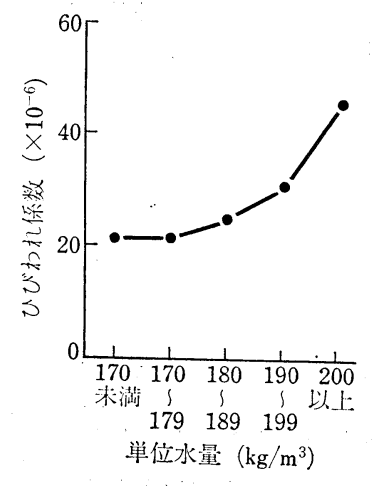

図一15.1 単位水量とひび わ机保数
ひびわれの発生が従来より少ないと報告されているよう です。

ひびわれ発生の要因でコンクリートの材料, 配(調)合 に関連するものは，セメントの種類と単位量および単位 水量が主で，ひびわれの発生を少なくするためには，七 メント量および単位水量をできるだけ少なくすることが 最も有効とされています。

ひびわれの発生量について, 主として打放しの建物の 外壁を対象にした追跡調查（216 件）の結果を分析した 報告 ${ }^{5)}$ では，図一15.1 に示されるように，単位水量が小 さいほどひびわれ係数（ひびわれ幅の合計 $d$ と壁の長さ lとの比）が小さくなっており，ひびわれが少なくなっ ていることが認められます。

流動化コンクリートの単位水量は, 通常の軟練りコン クリートと比較するとかなり減少し, かつ単位セメント 量も小さくなることから,ひびわれ発生量は大幅に減少 するものと考えられます。

\begin{tabular}{|l|l|}
\hline Q16 & $\begin{array}{l}\text { 流動化コンクリートの歴史はまだ } \\
\text { 浅いと思いますが, 耐久性上の問題 } \\
\text { はないのかどうか教えて下さい。 }\end{array}$ \\
\hline
\end{tabular}

コンクリートの寿命は半永久的とされてい

[A] たものが，昭和 50 年代になって海砂問題が 発生し，また最近ではアルカリ骨材反応問題 がクローズアップされるようになり，コンクリートの耐 久性が社会問題にまで発展してきていることは, 我々コ ンクリートに携わる者として本当に残念でなりません。

この背景として, 昭和 40 年代の高度経済成長期に多 量のコンクリートが消費され，良質の骨材資源が枯渴し て海砂, 砕石, 低品質骨材の利用を余儀なくされるよう になったこと,さらには省力化, 高能率化のためにコン

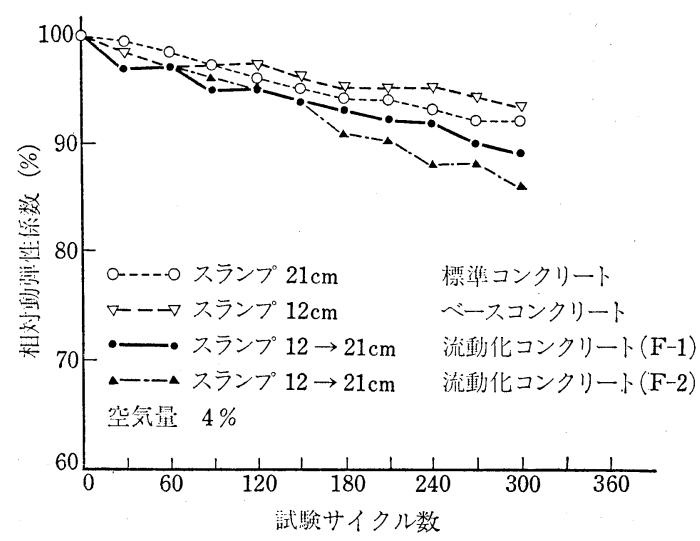

図一16.1流動化コンクリートの凍結融解に対する 耐久性 ${ }^{3)}$ 


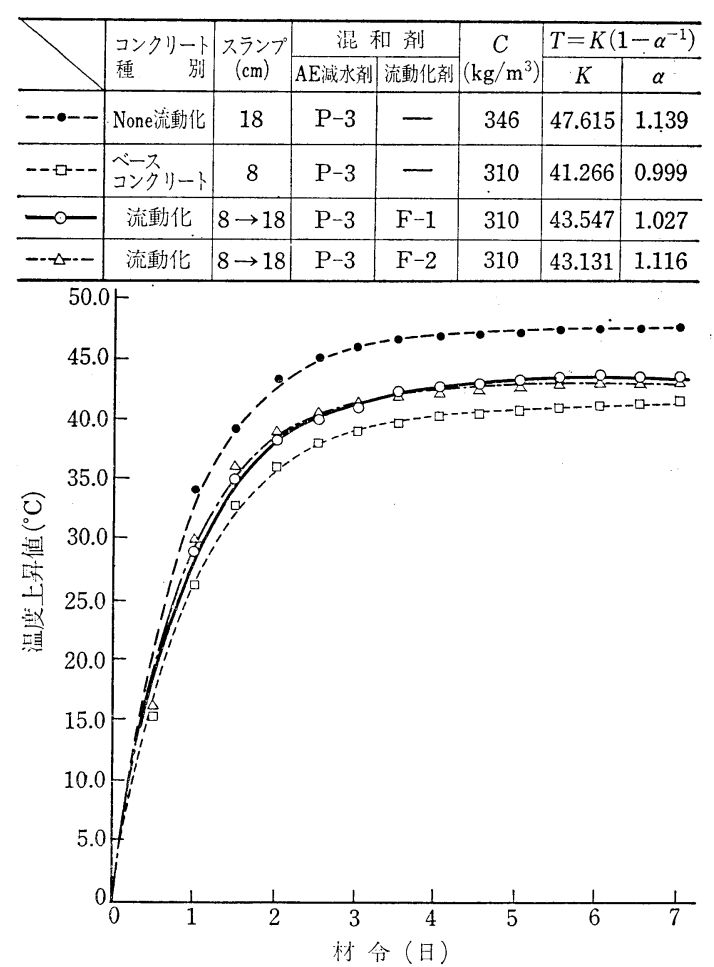

図一16.2 断熱温度上昇試験結果 ${ }^{3)}$

クリートポンプが利用されるようになってきたこと等に よって, 単位水量の多いコンクリートが用いられ, 品質 低下につながったものといわれています。

このような状況の下で, コンクリートの品質を改善し 耐久性を向上させるために登場したのが流動化コンクリ ートです。流動化コンクリートは, 低スランプのコンク リートに流動化剂を添加することによって流動性を高め 施工するもので, 流動化する前のコンクリート (ベース コンクリートと呼ばれる) の品質が保持できる特長があ ります。従って, 特に建築の軟練りコンクリートの品質 向上策として有効な手段といえます。

流動化コンクリートの耐久性では, ひびわれ, 長期強 度, 中性化速さ, 鉄筋の腐食, 凍結融解抵抗性, アルカ リ骨材反応性等, 様々な特性が明らかになってきていま すが，いずれの性質も非流動化コンクリートに比べ，同 等か, それより優れた結果が得られています。

ひびわれについては，Q15 でも説明しましたように 乾燥收縮量の減少による効果が期待できますし, セメン 卜量の減少に伴ってマスコンクリートでの温度ひびわれ の減少が期待されます。強度性状においても特に不利な 要素はありません。また, 鉄筋の腐食の原因となる中性 化はベースコンクリートによって支配され, 流動化によ る影響弪められません。海砂使用地域では, 単位水量 の低減策としてかなり利用されています。ちなみに, 現
在市販されている流動化剤には塩分は含まれておりませ L。

凍結融解抵抗性は, 連行されている空気泡に支配され たことが知られています。図一16.2 で流動化コンクリ ートは若干低下が認められますが, 適正な空気量が確保 されれば十分な耐久性を示します。

アルカリ骨材反応では，その現象が認められるまで長 期間を要しますが, 流動化コンクリートでの被害例の報 告はまだありません。アルカリ分の主供給源がセメント にあるといわれていますから，流動化による単位セメン 卜量の減少は有利に作用するものと考えられます。

\begin{tabular}{|l|l|}
\hline Q 17 & $\begin{array}{l}\text { 流動化コンクリートを採用するこ } \\
\text { とによりマイナスとなる点があった } \\
\text { ら教えて下さい。 }\end{array}$ \\
\hline
\end{tabular}

十分な管理の下に施工された流動化コンク

[A] リートの品質は, 前述のように硬練りのベー スコンクリートと同等であり, 何らマイナス になる点はないといえますが, 現場で流動化コンクリー 卜を施工する段階では, 従来の軟練りコンクリートに比 較すると多少異なった扱いを必要としますので, 必ずし もマイナス面とはいえないまでも，十分に注意すること が要望されています6)。

（1）圧送負荷

流動化コンクリートのポンプ圧送負荷はベースコンク リートよりは低減しますが, 同一スランプの通常コンタ リートよりは大きくなります $3{ }^{3,6)}$ 。

(2) 打設時の要員

流動化コンクリートは, 同一スランプの通常コンクリ 一トより単位水量が少なく粘性が大きいので, 締固めは 十分に行う必要があり，またブリージングが少なく，表 面の水引きが早いため, 押えのタイミンングも早くなりま すので, コンクリートエ, 左官工等の要員は, 通常より 若干多くする必要があります。

(3) 生コン車の積載量と損耗

現場で流動化する場合には，擋拌により均一化する必 要がありますので, 積載量は若干少な目にする必要があ り, また高速擋拌を行いますので, 擋拌系統の機械損耗 も通常のコンクリートより大きくなることを考慮する必 要があります。

(4) 生コンの受入れ検査

流動化の前にスランプの状態を全車について目視検查 を行う必要があり, 流動化作業と併せて担当員が必要と なります。また, 荷卸し地点におけるベースコンクリー トの検査は，JIS A 5308 に適合した試料採取ができま せんので, 別途に協議して決めておく必要があります。 
表一17.1 騒音測定結果 ${ }^{3)}$ (NA-09 型騷音計, $d B(A)$ )

\begin{tabular}{|c|c|c|c|c|c|}
\hline 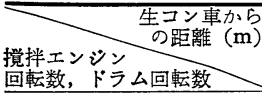 & 1 & 10 & 20 & 30 & 50 \\
\hline 高進 $(2000,16 \mathrm{rpm})$ & 99 & 89 & 84 & 80 & 76 \\
\hline 中 進 $(1000,12 \mathrm{rpm})$ & 94 & 81 & 74 & 70 & 66 \\
\hline
\end{tabular}

(5) 騒音対策

流動化する際に生コン車のドラムを高速回転して擋拌 しますが，この時に発生する騒音は，立地条件によって 規制される場合がありますので，市街地では特に近隣へ の影響を考慮する必要があります。また，やむを得ず建 物内で流動化する場合は, 生コン車の排ガスによる作業 者への影響にも配慮することが必要です。
参 考 文 献

1）福士 : 流動化コンクリートの 調合に関する 実験的研究, 住宅都市整備公団 住宅都市研究試験所研究報告集, No. 1,1983

2）土木学会 : 流動化コンクリート施工指針 (案), コンクリ ートライブラリー, No. 51, 昭 58.10

3）日本建築学会 : 流動化コンクリート施工指針案・同解説, 1983

4）小長井ほか : 流動化剤を 添加した 舗装コンクリートの性 状, セメント・コンクリート, No. 422, 1982

5）山根: コンクリート構造物のひびわれのパターン, 原因, 補修, 事前の低減対策とその費用, セメント・コンクリ ート, No. 451, 1984

6）杮崎ほか：高性能減水郕を 使用する上での 注意事項一流 動化コンクリート, コンクリート工学, Vol. 18, No. 7, 1980

（福馬直昭） 